\title{
The Role of a Digital History Book in Implanting Heroic Values for the Millennial Generation
}

\author{
Baharuddin Fathoni, Leo Agung Sutimin, \& Hieronymus Purwanta \\ Department of Historical Education, Faculty of Teachers Training \& Education, Postgraduate Program, Universitas \\ Sebelas Maret, Surakarta, Indonesia \\ baharuddinfathoni@student.uns.ac.id \\ *Corresponding Author: baharuddinfathoni@student.uns.ac.id
}

\begin{abstract}
Facing the era of globalization, the younger generation continues to experience an identity crisis where the younger generation is more familiar with hero figures who do not reflect eastern values, especially those that are typically Indonesian which causes the young generation to lack concern for the nation; and reduced pride in Indonesia's nationalistic identity. Digital books or e-books are a technological development that utilizes computers used to display information in the form of text, images, audio, video and other multimedia in a concise and dynamic form that can be read by computers or other electronic devices. In this case, digital books are an alternative and the right solution for learning the history of heroism in the implementation of independent learning. The purpose of this paper is to determine the role of digital history books in teaching heroic values to students. This research is analyzed using qualitative research methods. The results and discussion are: the role of learning the history of heroes through digital book media that can make it easier to teach heroic values to students. So that students are able to emulate heroic values and actualize and serve as spirit values in the life of society, nation and state.
\end{abstract}

Keywords: digital history book; heroism; young generation;

\section{Introduction}

In the current era of globalization, there is a very rapid development of technology and science, including in the field of education. The development of technology in the field of education allows changes in the implementation of education to become more modern. Through the development of technology, teachers are required to utilize technology which is used as a medium in learning, one of which is the development of multimedia or digital media in learning. However, the reality in class shows that in general history learning is still carried out classically with the lecture method. According to Taufik Abdullah (1997), the history learning strategy is still seen as very weak. The impact, history learning tends to be monotonous, saturating, boring, for students (Abdullah, 1997; Sulistyo et al, 2020; Arman et al, 2020).

One form of technology use in history learning is digital books. Digital books or shortened e-books, or electronic books, are digital forms of printed books. For printed books, which generally consist of a pile of paper containing bound text and images, e-books contain digital information which can contain text, images, audio or video. In general, digital books are more in demand because of their practical shape when compared to ordinary printed books, besides digital books have a search feature so that words in digital books can be easily found. The use of e-books has several advantages, namely: It is easier to carry in many files, the teacher does not run out of teaching materials for students, can reduce the burden on teachers in presenting information, information provided through e-books is more concrete, allows individual learning to participants students because they do not depend on the information provided by the teacher (Hasbiyati, 2020: 7; Lufthansa et al, 2019; Kusmawati et al, 2019).

Digital books are a new breakthrough in the world of education by utilizing technology to integrate literacy. Digital books are able to turn conventional books into electronic books using data that can be opened using portable digital devices. The presence of digital books in the world of education proves that education is progressing. It is hoped that the advantages of digital books will make people more fond of reading and easier to access because digital books have very sophisticated features (Jannah et al., 2017: 186; Permana \& Utomo, 2021; Rizanty et al, 2021). 
With the rapid development of technology, researchers have chosen digital books as a new medium that has emerged as a means and solution in teaching heroic values to the millennial generation. With digital book media, it can contain images and videos along with articles that are able to attract users, especially students, in addition, digital book media can have a positive impact and help teach heroic values with pictures of heroes and their explanations which later can be read and understood by the users. In addition, the delivery of the history of heroes using digital book media is expected to teach heroic values to readers, especially for students. That way history learning will be conveyed effectively and attractively.

History as revealed by Abdullah is to prepare valuable experiences that can provide wisdom (Abdullah, 1985). Therefore, it is important to learn history so that someone can take lessons from events that occurred in the past. Building knowledge and understanding in facing the future is very important and is still needed from an educational perspective (Pusbangkur, 2012). In history learning is a subject that emphasizes knowledge and values regarding the process of change and development of society from the past to the present (Depdiknas, 2004). One of the values that can be taken in the history of heroes is heroic values. With these hero values a child can maintain an identity as nationalist patriotism and can understand the true meaning of life.

According to Kabul Budiyono (2007), historical education which is oriented towards the cultivation of values, such as heroism, the spirit of struggle, nationalism, and nationalism, is felt to be very important to foster the patriotism of students, amidst the challenges of globalization which presents a hero who does not Eastern values, let alone Indonesian ones (Budiyono, 2007). An example is the spread of heroic values presented by Hollywood films, which are adapted from cartoons such as Superman, Spiderman, Hulk, Captain America, Superheroes, and others, which do not reflect the heroism possessed by the Indonesian people. The result is, there has been an identity crisis, especially among the younger generation, the lack of care of the young generation for the nation; and reduced pride in the identity of Indonesian nationalism (Wiriaatmadja, 2002; Pratikno et al, 2020; Novita et al, 2020; Hendratno \& Yermiandhoko, 2020).

A great nation is a nation where the people understand and understand their identity, society, and nation. They are aware of the current situation and conditions, which are shaped by the past and will be incarnated in the future, so that they have the knowledge and values to deal with problems throughout the ages (Wiriaatmadja, 2002; and Wineburg, 2006). For this reason, it is felt necessary to explore, reconstruct, and bring back these heroic values. Based on the background of the writing problem above, it can be formulated as follows: "How can the role of digital books in learning history instill heroic values in the millennial generation". Therefore, the purpose of this paper is to determine the role of digital books in cultivating heroic values to students which are expected to be able to fortify themselves by having heroic values.

\section{Methods}

This research was conducted using a qualitative descriptive approach, namely research that attempts to provide an accurate explanation of several social situations in the form of a sentence description and the data is not related to numbers (Arikunto, 2006). The method used in this research is literature study or library research and by conducting observational studies from previous studies. Research library (library research) Researchers study and collect data through several literature and reading sources that support and are relevant to the research. In this case, library research is carried out through books, magazines, the internet and so on.

\section{Results and Discussions}

\subsection{The Nation of E-Books}

The development of cology affects the world of education, which has led to new innovations in technologybased learning. One of the new innovations in education is digital books or e-books. Digital books or e-books (electronic books) are a technology development that utilizes computers used to display information in the form of text, images, audio, video and other multimedia in a concise and dynamic form that can be read by computers or other electronic devices (Ruddamayati, 2019).

Digital books in the world of education can increase the interaction between teachers and students in distance learning and students are more interested in using digital books in learning. Digital books or ebooks are textbooks that are converted into digital format, e-books also have the meaning of a learning environment that has applications that contain a multimedia application database as an instructional resource that stores multimedia presentations on topics in a book (Shiratuddin, 2011:3) A new innovation in the form of digital books is made with the aim of making it easier for readers to access books and literacy sources. Digital books have the advantage of being portable, efficient, attractive, cheap, and easy to store. 
The development of digital books nowadays is more creative and attractive with very diverse views. Meanwhile, digital book designs that are very popular with the public are digital books with threedimensional e-book technology or better known as flipbooks, where pages can be opened like reading a book on a screen (Riyanto, 2014: 7).

The features of digital books are great from an educational point of view. Text in digital books is hypermedia, so readers can use the included hyperlinks to jump to related topics, and text can contain graphic, audio, and video elements. In addition, digital book content can be easily changed to suit the needs of readers by changing or deleting unwanted text. Digital books also help teachers compile a collection of information on a computer that students can download at any time if needed (Smaldino E. S, 2011).

\subsection{The History Learning}

History is a reconstruction of the past, reconstruction in that history is what people have thought, said, done, felt and experienced. History is also a science that studies events in human life in the past. History describes a lot of facts, time sequence and place of occurrence of an event. History in its form provides an understanding of the past. History is not just giving birth to a story from an event of the past but understanding the past which contains various dynamics, may contain problematic lessons for the next human being. History is also a branch of science that studies systematically the whole development process of change and the dynamics of people's lives with all aspects of their life that occurred in the past (Kuntowijoyo, 1995: 18).

In the life of the nation and state, history learning has a strategic meaning. Learning history is a process to help develop the potential and personality of students through historical messages so that they become wise and dignified citizens of the nation. History in this case is the totality of human activity in the past (Walsh, 1967), and it is dynamic. It means that the past is not something final, but is open and continuous with the present and the future. Therefore, history can be interpreted as a science that systematically examines and studies the overall development of society and humanity in the past with all aspects of its occurrence, so that it can provide an assessment as a guide for determining the present state, as well as a mirror for the future. (Sadirman, 2005). So history learning serves to foster historical awareness. Historical awareness is an intellectual orientation, and an attitude of the soul to understand its existence as a human being, a member of society, and as a nation (Soedjatmoko, 1986). Taufik Abdullah (1974) emphasized that historical awareness is nothing but self-awareness. Self-awareness can be interpreted as being aware of one's existence as an individual, as a social being, including being aware as a nation and being aware as a creature of God (Sardiman, 2005).

History learning is one of the subjects that foster and shape citizens for a better nation-building. Learning history is also a bridge to nationalize the attitude of nationalism in students. So that the more students learn history, the more historical values are lived by students, which in the end students' learning achievement in the field of history increases (Chaerulsyah, 2014: 138). Learning history in schools aims to provide students with the ability to think historically and understand history. Students are able to develop competencies to think chronologically and have knowledge of the past that can be used to understand and explain the processes of development and change in society through teaching history. The purpose of learning history is to instill the spirit of love for the country, to know the process of forming the Indonesian state, to increase a sense of unity and oneness for students, and to know the process of Indonesian human civilization in particular and world society in general from the past to the present (Agung, 2012: 417).

\subsection{The Notion of Hero}

The word "hero" comes from the Sanskrit word phala-wan which means someone who from himself produces quality fruit (phala) for the nation, state, and religion (Edward, 2013). However, in an institutional context such as a state, the word hero is a formal award agreed upon by the components of the nation, which is subsequently ratified by a political official, namely the president, in official Indonesian regulations. Indonesian national heroes (Sutijo, 2009) A hero is a person who stands out for his courage and sacrifice in defending the truth, or a brave warrior (Mulyono, 2011).

Hero or Hero is a heroic act for the good of many people which is done by someone out of personal kindness. This heroic action was carried out in an effort to serve others or the community voluntarily without expecting any reward or material gain (Kurniawan, 2015). The heroine appears when his actions are seen as actions that "cannot be achieved by most people." Heroes are determined based on their 'unique' actions when faced with certain situations, or based on heroic actions that others are unwilling to do, because of very high risk factors (Venter, 2005: 102).

According to Schlenker, Weigold and Schlenker (2008) heroes have principles, are honest, spiritual in nature and have a positive orientation towards others (p. 323). They discussed the relationship between culture and the concept of heroism. Heroes refer to goals, norms and ways of behaving. Therefore, we can 
understand that in many ways heroes are role models in society. A hero is someone who has inspirational goals and is devoted to the norms prevailing in society. Therefore, heroes are presented to create a better society. Heroism is defined as a combination of courage as well as determination, selfishness, a sense of understanding (as a citizen) and the attitude of putting personal matters aside. All of these criteria become one behavior which then forms an action called heroism (Harvey, 2009: 313).

A hero is a patriot in spirit, where a patriot of the nation in the struggle has contributed much to the State. A hero is someone whose actions are successful for the benefit of people. His actions affect the behavior of others because they are considered noble and beneficial to the interests of the nation's people or mankind (Siti Khomsah, 2015: 12). In Indonesia, National Hero is a title given to an Indonesian citizen or someone who fights against colonialism in an area that is now Indonesia's territory who has died or died in defense of the nation and state, or who during his lifetime committed heroic acts or produced outstanding achievements and works usual for the development and progress of the nation and state of Indonesia (Nur Fatin, 2018).

\subsection{Heroic Values}

Value is a description of what is desired, appropriate, valuable, and influences the social behavior of those who choose that value (Lawung, 2009: 22). It is an idea that validates a meaningful or not practice and achieves the final result that becomes a guideline for designing a change. Value has the meaning of a collection of feelings or assumptions about something about good-bad, right-wrong, proper-inappropriate, noble-despicable, or important or insignificant (Yudhistira Sociology Team, 2003: 99). Value is the idea of whether experience is meaningful or insignificant, values also direct a person's behavior and judgment in making decisions (Paul B.Horton \& Chester L. Hunt, 1999: 71).

Value is something that is valuable, quality, shows quality, and is useful for humans. Something is said to be valuable if it is valuable or useful for human life. The existence of these two values is in line with the assertion of Pancasila as an open ideology. The formulation of Pancasila as an open ideology contained in the preamble of the 1945 Constitution paragraph 4 is stated as a basic value and its translation as an instrumental value. The base value has not changed and cannot be changed again. However important the basic values stated in the Preamble to the 1945 Constitution, they are not yet operational. This means that it cannot be translated directly into everyday life. The explanation of the 1945 Constitution itself points to the existence of a law as the implementation of the basic written law (Paulus Wahana, 2004: 122).

Heroic values are one of the things that must be emulated and used as an example, because over time people often become more individualistic (Henk Schulte, 2008: 172). The things that are meant by heroic values are: (a) willing to sacrifice, namely being willing to be sincere, happy, without expecting anything in return, and willing to give part of what is owned even though it causes suffering for him; (b) love for the motherland, namely the feeling of love for the nation and country itself; (c) hard work, namely striving wholeheartedly with all my might to strive for the desire to achieve maximum results in general; (d) exemplary, namely a positive attitude that can be used as a reference by the community; (e) honesty, namely the conformity of the news conveyed with the existing facts; (f) democratic, namely a choice of a nation to adhere to the notion of freedom of opinion by means of deliberation and consensus; (g) independent, namely doing something without depending on other individuals; and (h) responsible, namely the condition of being obliged to bear everything that has been done. From the explanation above, it can be concluded that value is something that is important, good, and valuable. In the value contains something ideal, the aspiration to aspire to goodness. Judging means weighing an activity, relating something to another and then making a decision. Something is considered to have value if something is considered important, good, and valuable to human life, whether from a religious, political, legal, moral, ethical, aesthetic, economic or socio-cultural perspective.

\subsection{The Role of Digital History Books as Alternatives and Solutions to Teach Heroic Values for Millennial Generation}

The development of ecology makes it easy in the world of education to give birth to new innovations in technology-based learning. One of the new innovations in education is digital books or e-books. Digital books or e-books (electronic books) are a technology development that utilizes computers used to display information in the form of text, images, audio, video and other multimedia in a concise and dynamic form that can be read by computers or other electronic devices (Ruddamayanti, 2019).

Learning history, will develop the activities of students to study various events, to then be understood and internalized to themselves so as to give birth to examples of behavior and action. Of these events, among others, there are messages related to heroic values such as exemplary, willingness to sacrifice, love for the country, togetherness, independence, equality, nationalism and patriotism (see Kabul Budiyono, 2007). Some of these values can be explored and developed through meaningful historical learning. For this reason, the 
creativity of history teachers is highly demanded.

The presence of digital books indicates that there are technological developments in the world of education which are expected to facilitate teaching and learning activities. In general, digital books are more in demand because of their practical shape when compared to ordinary printed books, besides digital books have a search feature so that words in digital books can be easily found. Publication of ins pirational text and images and videos in digital form that are made and published and can be read anywhere and anytime using electronic devices such as smartphones and laptops (Andina, 2011: 4). Digital books are an evolution of digitalized printed books and are a new innovation in the world of education which presents a practical and efficient book that can be opened anywhere and anytime (Subiantoro, 2014).

The value of heroism refers to an adjective that deserves to be upheld. The value of heroism is seen as a value which means something that is valued or upheld, which is associated with the formation of character or character. So that learning history is very important to teach heroic values to students, in order to teach heroic values so that they can shape student character. The values of heroism, which include values of selfsacrifice, selflessness, belief in one's own abilities, and never back down, can be an inspiration and motivation for students to become the next generation with character. These heroic values must be revitalized and actualized and used as spirit values in the life of society, nation and state. Budiyono argues that children who are less inculcated with patriotism will have an impact when they grow up, namely the loss of their sense of sensitivity. and attention to various national problems that arise or at least the various events that occur in the environment where they live. Whereas the quality and integrity of the nation in the future depends on our quality and awareness in providing education both scientifically and in cultivating the values of patriotism in children, because those children will replace our current leaders in the future ( Budiyono, 2007).

\section{Conclusion}

In the current era of globalization, knowledge and skills are needed by students to develop themselves in finding and giving birth to creative ideas in making attitudes and decisions. The use of historical digital books in learning is a new innovation in the world of education that combines technology and learning. Through the media of digital history books, students will find it easy to get information, they are interested in seeing photos or videos accompanied by writings so that the values of heroism will be conveyed effectively. The use of this digital book will also make it easier for students to understand and live up to the heroic values presented by combining audio and visual elements, so that heroic values include values of being self-sacrificing, selfless, believing in their own abilities, and never going backward. , can be an inspiration and motivation for students, to become the next generation with character. These heroic values must be revitalized and actualized and used as spirit values in the life of society, nation and state. The presence of this digital book is also expected to be able to assist teachers in delivering material which is constrained by distance because they cannot face their students directly. The advantages of digital books that are practical and can be opened anywhere will make it easier for students to be able to read and it is hoped that students can absorb the heroic values of what they have read.

\section{Acknowledgement}

The authors would like to thanks to the people who have been instrumental in their assistance and the successful completion of this study.

\section{Author's Contribution}

All authors discussed the result and contributed to from the start to final manuscript.

\section{Conflict of Interest}

The authors declare that they have no competing interests.

\section{References}

Abdullah, T. (1997). “Di Sekitar Pengajaran Sejarah yang Refl ektif dan Inspiratif” dalam Jurnal Sejarah, No.6. Jakarta: MSI [Masyarakat Sejarawan Indonesia].

Abidin, Z. (2016). Pemanfaatn Media Sosial Sebagai Ruang Belajar Siber Pada Pendidikan Di Era Digital. Jakarta Pusat : Simposium Guru 2016. 
Arman, A., Winarsih, M., \& Ibrahim, N. (2020). The A6S Information Literacy Model for Digital Age Library instruction. International Journal for Educational and Vocational Studies, 1(8), 831-837.

Affan, M. H. (2016). Membangun Kembali Sikap Nasionalisme Bangsa Indonesia Dalam Menangkal Budaya asing di Era Globalisasi. Jurnal Pesona Dasar, Vol. 3, No. 4

Arikunto, S. (2006). Prosedur Penelitian Suatu Pendekatan Praktek. Jakarta : Rineka Cipta, 2006.

Asyhar, R. (2012). Kreatif Mengembangkan Media Pembelajaran. Jakarta: Referensi Jakarta.

Badrun. (2006). Pahlwan. Jakarta : Perspektif, 2006.Budiyono, Kabul. 2007. Nilai-nilai Kepribadian dan Kejuangan Bangsa Indonesia. Bandung : Alfabeta, 2007.

Budiyono, K. (2007). Nilai-nilai Kepribadian dan Kejuangan Bangsa Indonesia. Bandung: Alfabeta.

Chaerulsyah, E. M. (2014). Persepsi Siswa Tentang Keteladanan Pahlawan Nasional Untuk Meningkatkan Semangat Kebangsaan. IJHE, Vol. 3 No.1

Divayana, D., G.,H., P. W., A. S., and Agus A. (2018). “Pelatihan Pembuatan Buku Digital Berbasis Kvisoft Flipbook Maker Bagi Para Guru Di Smk Ti Udayana." Abdimas Dewantara.

Prasetya, D. (2015). Kesiapan Pembelajaran Berbasis Buku Digital.\| Jurnal Teknologi Elektro Dan Kejuruan Vol. 24 , no. 2.

Evers, H., D. (1988). Teori Masyarakat: Proses Peradaban dalam Sistem Dunia Modern. Jakarta: Yayasan Obor Indonesia.

Fathurrohman, M. (2015). Model-Model Pembelajaran Inovatif. Jogyakarta: AR-Ruzz Media.

Hasbiyati, H. (2020). “Analisa Efektifitas Penerapan Media Pembelajaran Berbasis Smartphone Pada Peningkatan Hasil Belajar Biologi." Bio-Lectura. doi: 10.31849/bl.v7i1.4034.

Hendratno, H., \& Yermiandhoko, Y. (2020). Development of Learning Textbook Based ICT For Master's Student of Primary Education. International Journal for Educational and Vocational Studies, 2(5).

Kuswinardi. (2009). Pengembangan Sistem Konten Electronic-Book Terpadu Untuk Media Pembelajaran Berbasis Web. Jurnal Matematika dan Komputer Indonesia Vol. 1, No.2 Program Studi Manajemen Informatika Fakultas Teknologi Informasi Universitas Kanjuruhan Malang.

Kusmawati, W., Iza, N., Hindun, N., \& Nuh, F. A. (2019). Development of Textbooks on Animal Embryology and Reproduction Based on Research Results in the Development of Mice Embryos by Adding DEET (Diethyltoluamide). International Journal for Educational and Vocational Studies, 1(4), 345-348.

Lase, D. (2019). Pendidikan di Era Revolusi Industri 4.0. Jurnal Sudermann.

Lufthansa, L., Rusdiawan, A., Yahya, A., Pawitra, P. R. A., \& Sari, R. S. (2019). Results of the Feasibility of Material and Media Aspects of Teaching Books on Sports Nutrition. International Journal for Educational and Vocational Studies, 1(5), 448-450.

Marnawati. (2013). Kumpulan Pahlawan Indonesia Terlengkap . Jakarta Timur: Penebar Swadaya Grup, 2013.

Novita, E., Warsono, W., \& Wisnu, W. (2020). Discourse on Adolescent Deviant Behavior on Social Media Facebook: Indonesian Youth Group Caption. International Journal for Educational and Vocational Studies, 2(10).

Permana, D., \& Utomo, U. (2021). Learning Needs Analysis: Thematic Teaching Book Based on HOTS Assisted with 3D Stereoscopic Images to Improve Critical Thinking Ability of Elementary School Students. International Journal for Educational and Vocational Studies, 3(2), 116-123.

Pratikno, P., Suyono, S., \& Agustini, R. (2020). The Validity of Student Worksheets and Student Textbooks Inquiry Training Model on The Colligative Properties of Solution. International Journal for Educational and Vocational Studies, 2(11).

Rizanty, R., Fridani, L., \& Marjo, H. K. (2021). The Development of Self Help Book for Counseling Guidance's Teacher Experiencing Burnout Symptoms with Counseling Cognitive Behavioral Therapy. International Journal for Educational and Vocational Studies, 3(1), 44-48.

Soedjatmoko. (1986). Dimensi Manusia dalam Pembangunan, Jakarta: LP3ES.

Sulistyo, A. R. N., Mintowati, M., \& Suyatno, S. (2020). The Development of Digital Textbooks 来学汉语 lái xué Hànyǔ based on the 2013 Curriculum Cross-Major Courses of Mandarin for the Tenth Graders. International Journal for Educational and Vocational Studies, 2(6).

Wiriaatmadja, R. (2002). Pendidikan Sejarah di Indonesia: Perspektif Lokal, Nasional, dan Global. Bandung: Historia Utama Press.

Walsh, W.H. (1967). Philosophy of History : An Introduction. New York: Harper and Row Publisher. 